\title{
P. SEBASTIAN ERTEL AND HIS SACRED WORKS
}

\author{
MARTIN L. FIALA \\ Landesmusikschule Steyr
}

\begin{abstract}
Izvleček: Štajerski oz. zgornjeavstrijski skladatelj Sebastian Ertel (ok. 1550/60, Mariazell - 13. 7. 1618, Garsten) je v literaturi prisoten le s kratkimi biografskimi podatki in kritičnim katalogom, ki pa ostaja nepopoln. Kljub temu pa je ta skladatelj na Štajerskem in v Zgornji Avstriji zelo znan. Zapustil je obsežno zbirko duhovnih skladb iz časa med 1611 in 1617, ki pa večinoma doslej še niso bile temeljito analizirane. Z izjemo ene tiskane orgelske skladbe in nekaj zasebnih »prepisov" glasbeniki danes nimajo na voljo izvedbenega gradiva Ertlovih del. Prispevek odgovarja na vprašanji, kdo je bil benediktinski oče Sebastian Ertel in kaj ga povezuje s slavno leta 1615 tiskano antologijo Parnassus musicus Ferdinandaeus.
\end{abstract}

Ključne besede: beneška glasba, parodični magnifikati, parodične maše, Marijini himnusi, dvozborje, protireformacija.

\begin{abstract}
The Styrian - Upper-Austrian composer Sebastian Ertel (c. 1550/60 Mariazell - 13 July 1618 Garsten) appears in the literature only in the form of a brief outline of his biography and a catalogue raisonné of his music that omits some items. Nevertheless, he is a well-known figure in Styria and Upper Austria. He left an extensive collection of sacred compositions published in 1611-1617, most of which, however, have not yet been thoroughly analysed. Other than one single musical print for the organ and a few private manuscript "transcriptions" there are no musical scores or new published editions of his works that can be used in performances today. The article provides information on the identity of the Benedictine father Sebastian Ertel and on what connects him to the famous Parnassus Musicus Ferdinandaeus collection of 1615. Keywords: Venetian music, parody Magnificat compositions, parody masses, Marian hymns, double choir, Counter-Reformation.
\end{abstract}

In his book Die Musik im frühevangelischen Österreich, published in 1954, Hans Joachim Moser characterized the musician and priest Sebastian Ertel very appropriately with the following words: "One should take a closer look at this Bavarian-Austrian 'Gabrieli'."1

I choose to place this quotation by Moser at the beginning of my paper in order to introduce you to the many-sided figure of Sebastian Ertel and his extensive works with their consistently apparent connections to Venetian Music, thereby contributing, in a broader sense, to the topic of the Parnassus Musicus Ferdinandaeus (1615). Allow me to start by listing the possible links between the works of Sebastian Ertel and this anthology:

\footnotetext{
1 Moser, Die Musik, 41.
} 
First, Ertel's fondness for the Italian and Venetian Music of his time should be mentioned. Significantly, he used as models for his parody Magnificat compositions and parody Masses, in addition to his own works, ones by other composers, notably Andrea and Giovanni Gabrieli, Luca Marenzio, Leone Leoni and Annibale Perini (d. 1596 and working in Graz at that time) plus Georg Poss, who is similarly represented in the Parnassus anthology.

Further connections can be made through the political actions of Archduke Ferdinand II and the monastic links of the Benedictines to the ruling house and to Graz.

Sebastian Ertel lived at a time of inter-confessional disputes. Steyr, especially, was a hotbed of the Reformation, whereas the abbey in the neighbouring town of Garsten acted as its Catholic counterweight. Abbot Johann I Spindler of Garsten (1574-1589) was at the time striving to repress the Protestant religion in all parishes of the region under the control of the monastery in Garsten. In 1586 he declared his intention of once again staffing the parish church of Steyr "with Catholic priests from his abbey". ${ }^{2}$ Abbot Johann I failed in this aspiration, however, through opposition from the Protestant city council.

After the decrees promulgated by Emperor Rudolf on 27 August and 6 October 1597 for the implementation of the policy of re-Catholicization in the territories above the Enns became known, the city council and clergy prepared for the upcoming fight. The people of Steyr were anxious, the atmosphere highly charged. It was dangerous for clergymen in some parts of Steyr to walk on the streets visibly dressed in their habit. Sebastian Ertel, for example, gives a personal report in a document from the year 1599, of how he was nearly stoned to death in an area of Steyr. ${ }^{3}$

Abbot Johann I Spindler, who was called in 1589 to the Benedictine abbey of Kremsmünster, was succeeded in 1591 by Martin Alopitius (1591-1600) as the new abbot of Garsten. The latter made vigorous attempts to complete the work of reconversion to the Catholic faith initiated by Spindler.

Sebastian Ertel, who took his monastic vows under Abbot Martin Alopitius in 1596, was sent to the Protestant communities of Gaflenz and probably also to Weyer as a priest from the monastery. It is worth noting that the abbot of Garsten may have recognized Ertel's superior abilities as a chaplain, preacher and musician and chosen him specifically for the task of re-Catholicizing those communities.

In geographical terms, these were strongly Protestant areas which, in some remote valleys, have remained Protestant to this day. In 1599 Abbot Martin Alopitius was called to the abbey of St. Lambrecht in Upper Styria at the behest of Archduke Ferdinand of Inner Austria.

"According to the chronicle of Father Peter Weixler, Maria of Bavaria, the widow of Karl II, who had made acquaintance with Abbot Martin in Mariazell, was the driving force behind the promotion of Alopitius to the abbacy of Lambrecht." Martin Alopitius continued

2 Pritz, Beschreibung und Geschichte der Stadt Steyr, 223.

3 In the original: "Des Tumults zu Steyr jüngst 21. Juni abgeloffen, einfältiger eilender Entwurf und Abriss. Anno 1599 [...] Verzaichnus was sich mit mir Frater Sebastiano Ertelio den 21. Juni in Steyr begeben und zugetragen, da denselben Tag Frater Andreas, Schaffer, in Abwesenheit meines Gnädigen Herrn vom Kloster alhie aussgangen.” See: Oberösterreichisces Landesarchiv, Linz, Actenstück - Bericht über den Tumult zu Steyr 1599, Stiftsarchiv Garsten, Aktenband 69/ Nr. 12.

4 Plank, Geschichte der Abtei St. Lambrecht, 63. 
his counter-reformatory efforts at his new place of activity. In order to achieve his aims he needed the best-educated clerics from the University of Graz. The influence that the Jesuit faculty in Graz, where most monks studied theology, wielded over the musical life of the monasteries is difficult to assess. The monks brought new musical supplies, including precious musical instruments. Martin Alopitius made efforts to enlarge his monastery, partly by recruiting monks from other monasteries. However, during his abbacy also new, young men joined the order.

Sebastian Ertel from Garsten was among those who followed the abbot's call, serving from 1600 to 1605 as a priest (in the years 1600,1604 and 1605 he is mentioned in the parish registers of St. Lambrecht), as well as a music teacher for the choirboys and as a composer in Mariazell. In 1605 Ertel returned from St. Lambrecht to the monastery in Garsten, where he remained until his death in 1618 .

Counter-reformatory intentions obviously lay behind Ertel's assignment to St. Lambrecht. The pilgrimage site Mariazell, which attracted prominent believers, was overseen by the St. Lambrecht monastery. The intention was, on the one hand, to celebrate the services liturgically in a festive and grand manner, and, on the other hand, to improve the quality of the church music - a goal to be achieved by varying and enriching the musical composition as a whole. If the annals of a contemporary, Wolfgang Lindner, ${ }^{5}$ are to be trusted, it is likely that the bulk of the Magnificat compositions and the Marian hymns were written either in or for Mariazell. Moreover, the construction of an additional organ points to the influence of the Venetian school. This is how it comes to be that a high proportion of Ertel's Magnificat compositions and Marian hymns are scored for double choir (and two organs).

\section{Concerning Ertel's works}

Sebastian Ertel appeared in public as a choirmaster, composing instrumental music (e.g., his Tafelmusik of 1615) in addition to an extensive corpus of vocal music, and dedicated a collection of printed sermons in the year 1616 to the still Protestant Magistrat in Steyr. Following Ertel's death in 1618, the retired Imperial Kapellmeister, Alessandro Orologio, ${ }^{6}$ was temporarily active in Garsten during the years 1618 and 1619.

Sebastian Ertel composed his works primarily for purposes relevant to his place of activity, and mainly for liturgical use (Mass and Divine Office). His compositions nevertheless gained recognition far beyond the monastic domain and even achieved publication.

There exist several prints that were produced in Munich from 1611 through 1617 (published by Nicolaus Heinrich), and some of Ertel's works are also preserved in (partly incomplete) manuscripts. Many of his compositions are written for six to ten voices, whereby the pieces for smaller-sized ensembles are laid out in the traditional polyphonic style, while the pieces for eight voices are mostly kept homophonic and written for double choir. But even in the compositions for double choir we also encounter densely woven polyphonic structures (e. g., at the beginning of the Sanctus of the Missa super Benedictus).

\footnotetext{
5 Moser and Weber, Waidhofen an der Ybbs und Steyr im Blick, 162-163.

${ }^{6}$ Kellner, Musikgeschichte des Stiftes Kremsmünster, 158.
} 
Ertel employs a simple, syllabic style without melismatic elaboration for especially meaningful textual passages, while also using intelligently chosen melismata to emphasize selected words through music. Sebastian Ertel's varied compositional styles show him to be an early seventeenth-century "transitional" composer who wrote in the old style yet was already willing to accept elements of the new Italian baroque style into his music. He is one of the first composers within the area of Austria and southern Germany to introduce the basso continuo. Ertel's printed works are (naturally) preserved in partbooks.

The publication of an extensive collection of Sebastian Ertel's compositions, his Symphoniae sacrae, ${ }^{7}$ containing a total of 62 motets and Magnificat settings for variously six, seven, eight, nine and ten voices, occurred when the composer was already 50 years old.

Since the pieces in this great collection were probably not written immediately prior to their publication, it is most likely that the collection contains works originating from more than one of Ertel's creative periods. This hypothesis is supported by the different stylistic elements found in the individual compositions. Another noteworthy fact is their dedication to Abbot Martin Alopitius, with whom Ertel would at this point have enjoyed close relations for already twenty years.

The year 1613 is similarly the date of a collection of ten Masses by Sebastian Ertel in six, seven, eight and ten voices that was published by Nicolaus Heinrich in Munich. ${ }^{8}$ At least eight of these Masses may be classified as parody Masses. The Missa super Benedictus for double choir is the eighth of these Masses. The model for this parody Mass was the motet Benedictus es Salvator Israel (no. XIIII), likewise written for double choir, belonging to the collection Orpheus mixtus by Georg Poss. This had been published in Graz by Georg Widmanstetter in 1607.

Also, in this instance, the choice of model is suggestive of Ertel's counter-reformatory efforts, since his choice of a motet taken from a collection dedicated to the devoutly counter-reformatory Archduke Ferdinand of Inner Austria was not arbitrary.

The Masses' preface and their dedication to Johann Gottfried of Aschhausen (1575-1622, bishop of Bamberg and Würzburg) likewise testify strongly to Sebastian Ertel's counter-reformatory agenda. (Here, it should be added that the dedicatee was a prominent witch-hunter.)

Sebastian Ertel's Magnificat collection Sacrosanctum (1615) contains 35 pieces for double choir, among them numerous parody Magnificat compositions that demonstrate his connections to the composers attached to the court chapel in Graz. These uniformly scored compositions reveal a common inspiration: Orlando di Lasso.

7 Ertel, Symphoniae sacrae. I have consulted microfilms of all six parts (Cantus, Altus, Bassus, Quinta, Sexta, Septima) preserved in the collection of microfilms at the Musikwissenschaftliches Institut der Karl-Franzens-Universität Graz. The original prints used for microfilms are held today by Biblioteka Uniwersytecka, Wrocław (PL-WRu, Mus 297 at D 139/1-6) and Proskesche Musikabteilung, Bischöfliche Zentralbibliothek, Regensburg (D-Rp, D 139/1-4 [Tenor, Octava]).

8 I have consulted digital copies of the parts (Altus, Tenor, Bassus, Quinta Vox) made available by Bayerische Staatsbibliothek, Munich (D-Mbs, 4 Mus.pr. 532) in the collection Münchener DigitalisierungsZentrum - Digitale Bibliothek, and parts (Cantus, Altus, Tenor, Bassus, Sexta Vox, Septima Vox, Octava Vox, Pars pro Organo) from the already-mentioned collection of microfilms in Graz; the originals of which are found in D-Rp (A.R. 334). 


\section{Figure 1}

Title page of the Symphoniae sacrae (1611) by Sebastian Ertel (Bischöfliche Zentralbibliothek Regensburg, Proskesche Musikabteilung, D 139/1-4; reproduced with kind permission)

\section{Figure 2}

Cantus title page of Ertel's Missarum of 1613 (Bischöfliche Zentralbibliothek Regensburg, Proskesche Musikabteilung, A.R. 334; reproduced with kind permission)
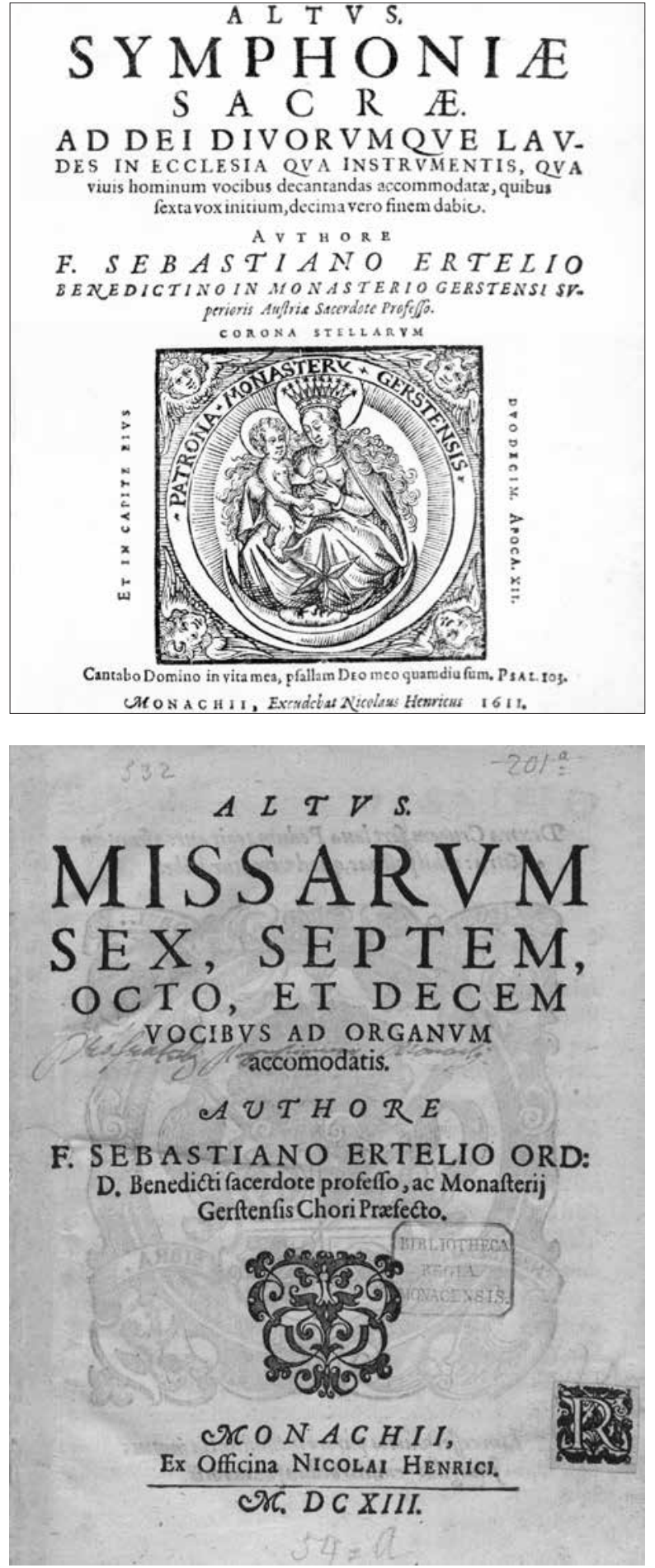
Sebastian Ertel's final collection, containing 22 vesper psalms for two choirs, was his Psalmodiae vespertinae (1617). ${ }^{9}$

The literature mentions, besides the definitely lost published work Hymnus B. Jacoboni Tudertini (for four voices, Munich, 1616 - probably a Stabat Mater composition), a set of Falsobordoni (for eight voices) as well as three Masses, five Magnificats and nine motets. ${ }^{10}$ The only print published in the twentieth century was that of Eberhard Kraus in the organ music series Cantantibus Organis (1962, which contains cadences in the eight church modes taken from the Sacrosanctum magnae et itemeratae Virginis canticum ${ }^{11}$ and an intabulation of a motet for eight voices, Tota pulchra es amica mea, taken from the tablature book FK 23 in the private library of the Thurn und Taxis family in Regensburg).

The final composition, Suffragia communia a 4 voc. (intercessions), contained in the manuscript collections of antiphons entitled Antiphonae vespertinae compiled by the choirmaster father Benedikt Lechler (1594-1659) from the Kremsmünster monastery, was likewise composed by Sebastian Ertel.

\section{On Ertel's compositions in greater detail and in comparison with European composers of his time}

A detailed analysis of Sebastian Ertel's extensive works would exceed the limits of this paper. Let me therefore focus on the subject of this conference and elaborate via a few selected examples his relationship with his contemporaries in Graz and Italy. In doing so, I am seeking to demonstrate through direct comparison Ertel's up-to-dateness and modernity for his time. I would like to start by comparing Ertel's parody Magnificat compositions from his 1615 collection with his respective models.

Especially noticeable and interesting is the fact that Sebastian Ertel takes several parameters, such as voice-leading, harmony, the melodic contour, the number of rests, the key signature, the number and arrangement of parts (and much more), directly from the models in question.

Gernot Gruber writes in his dissertation of 1964 on the adaptation of models in the parody Magnificat of the second half of the sixteenth century: "The characteristic technique in parodying is accordingly to begin with an opening that adheres strictly to the model and then increasingly departs from it [...] before returning at the end to a close adherence to the model." ${ }^{\prime 2}$

In appendix I give incipits for only the most significant correspondences between Ertel's Magnificats and his models. I have limited myself to comparisons with the previously

9 Ertel, Psalmodiae vespertinae. I have consulted the preserved partbooks (Cantus I \& II, Altus I \& II, Tenor I \& II, Bassus I \& II, Pars Pro Organo) in Benediktinerstift, Musikarchiv, Kremsmünster (A-KR, L33). This collection, edited by M. L. Fiala, is to be published in 2017 by the Cornettoverlag, Stuttgart.

${ }^{10}$ Eitner, "Erthel", and Mutschlechner, "Ertl".

${ }^{11}$ Ertel, Sacrosanctum. I have consulted the preserved partbooks (Cantus, Altus, Tenor, Bassus, Quinta Vox, Sexta Vox, Septima Vox, Octava Vox, Pars pro Organo) in A-KR (L34).

${ }^{12}$ Gruber, Beiträge, 202. 


\section{Figure 3}

The title page of Ertel's Sacrosanctum magnae et intemeratae Virginis canticum (Benediktinerstift Kremsmünster, L34; reproduced with kind permission)

\section{Figure 4}

The title page of Ertel's Psalmodiae vespertinae (Benediktinerstift Kremsmünster, L33; reproduced with kind permission)
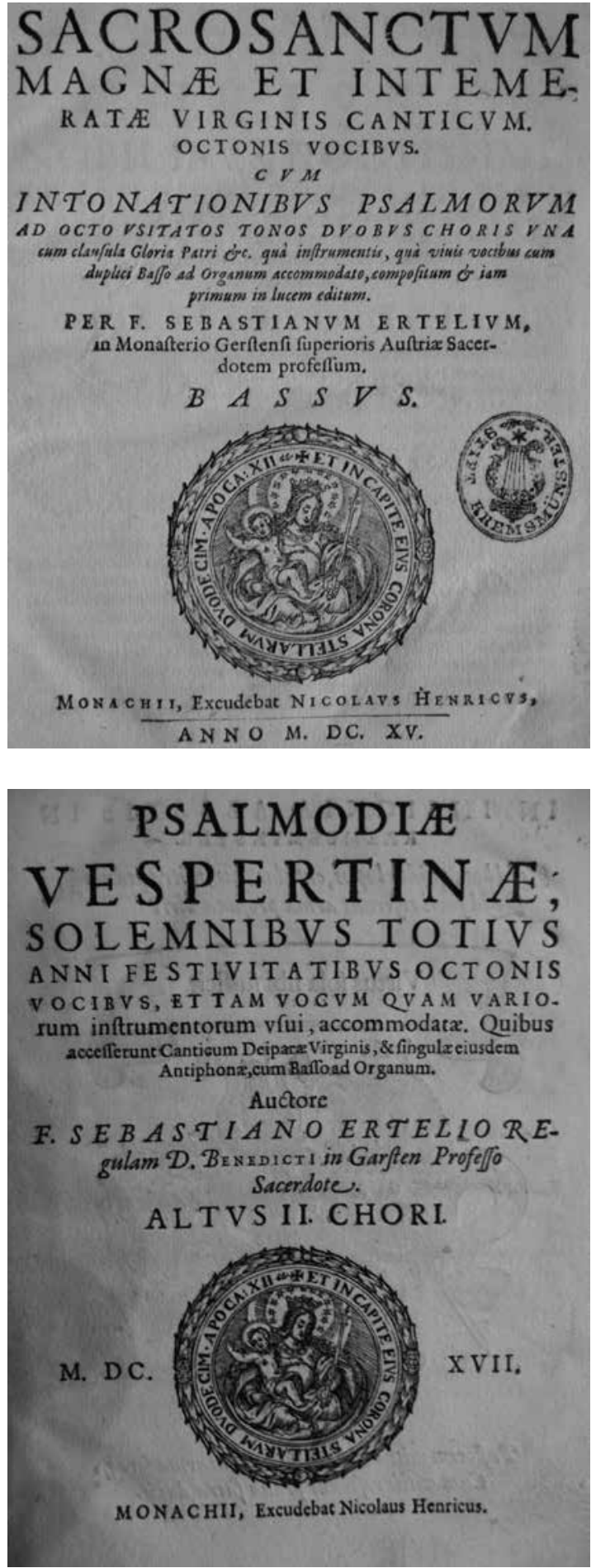
mentioned composers. Several of the models were composed by Ertel himself, being taken from his published Symphoniae sacrae of 1611.

In conclusion, I would now also like to illustrate the significant correspondence between Ertel's parody Masses and their respective originals. The examples show the correspondence between the motet for double choir Benedictus es Salvator Israel from the collection Orpheus mixtus by Georg Poss and the Missa super Benedictus by Sebastian Ertel, based on Poss's motet in its Kyrie and also in its Gloria, Benedictus und Agnus Dei.

\section{Music Example 1a}

Georg Poss, Benedictus es Salvator Israel, bb.1-3 ${ }^{13}$

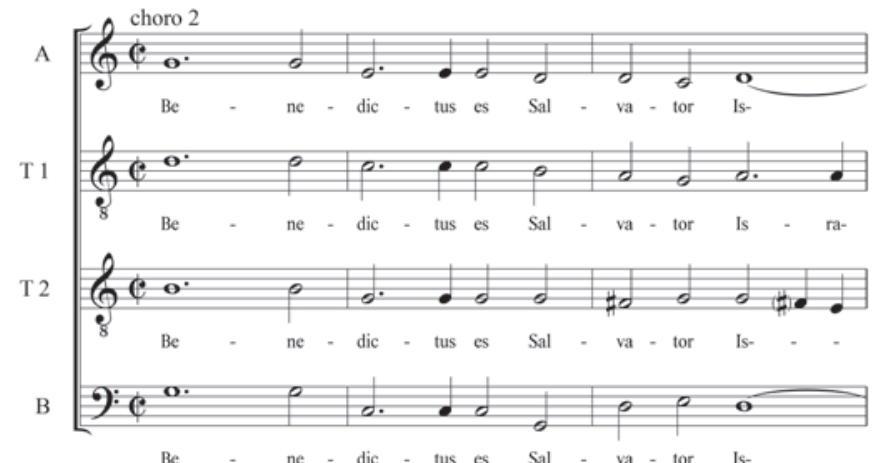

Music Example 1b

Sebastian Ertel, Missa super Benedictus (Kyrie), bb. 1-5

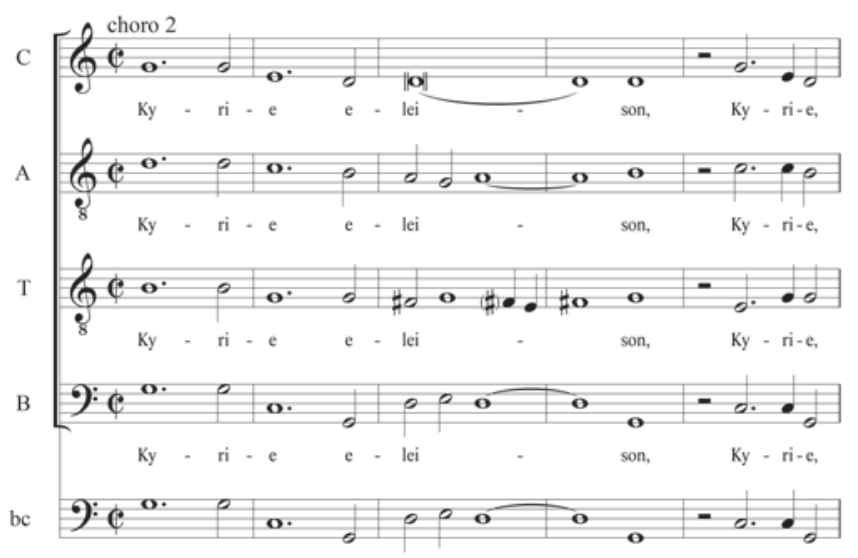

As a further example from later in the composition, I quote a second motif by Georg Poss, which Ertel takes up on several occasions in the Kyrie (starting at bar 47), in the Gloria (starting at bar 32), in the Qui tollis (starting at bar 40) and in the Agnus Dei (starting at bar 24).

${ }^{13}$ Poss, Orpheus mixtus. I have used the surviving print in D-Rp (A.R. 25-26). 
Music Example 2a

Georg Poss, Benedictus es Salvator Israel, bb. 35-37

A 1

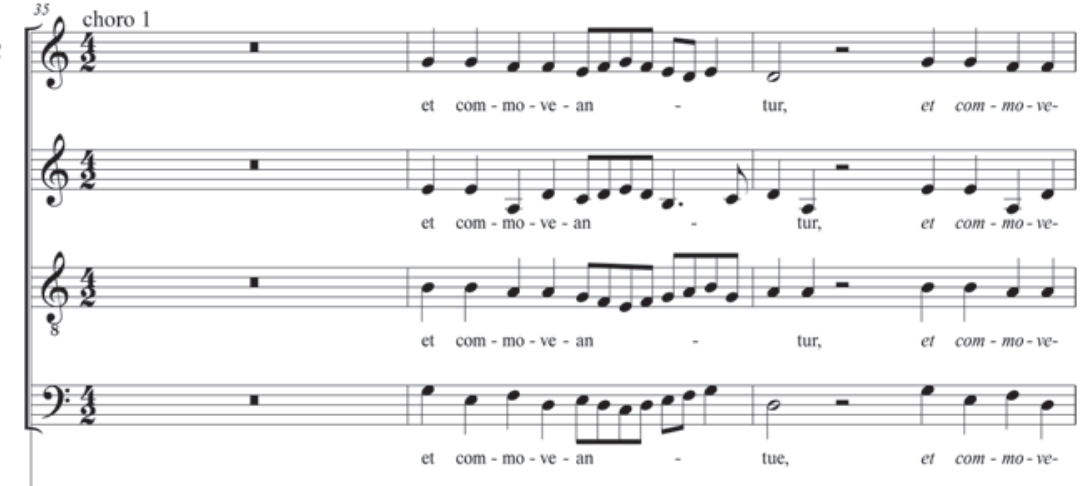

A 2

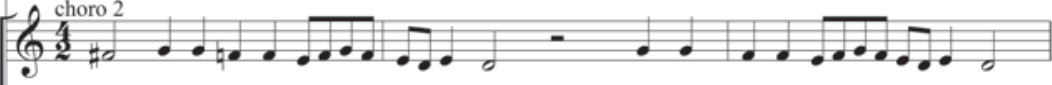

T 2

rum, et com-mo-ve - an $\quad$ tur,

et com - mo-ve - an

tur,

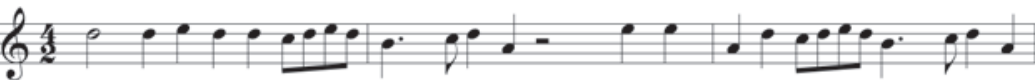

T 3

rum, et com-mo - ve - an tur, et com - mo-ve - an

tur,

3

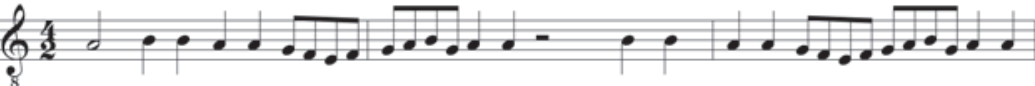

B 2

rum, et com-mo - ve - an

et com - mo-ve - an

tur,

2

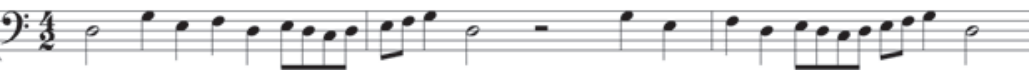

rum, et com-mo-ve - an - tur,

et com - mo-ve $=$ an $\quad$ tur 


\section{Music Example 2b}

Sebastian Ertel, Missa super Benedictus (Agnus Dei), bb. 21-25

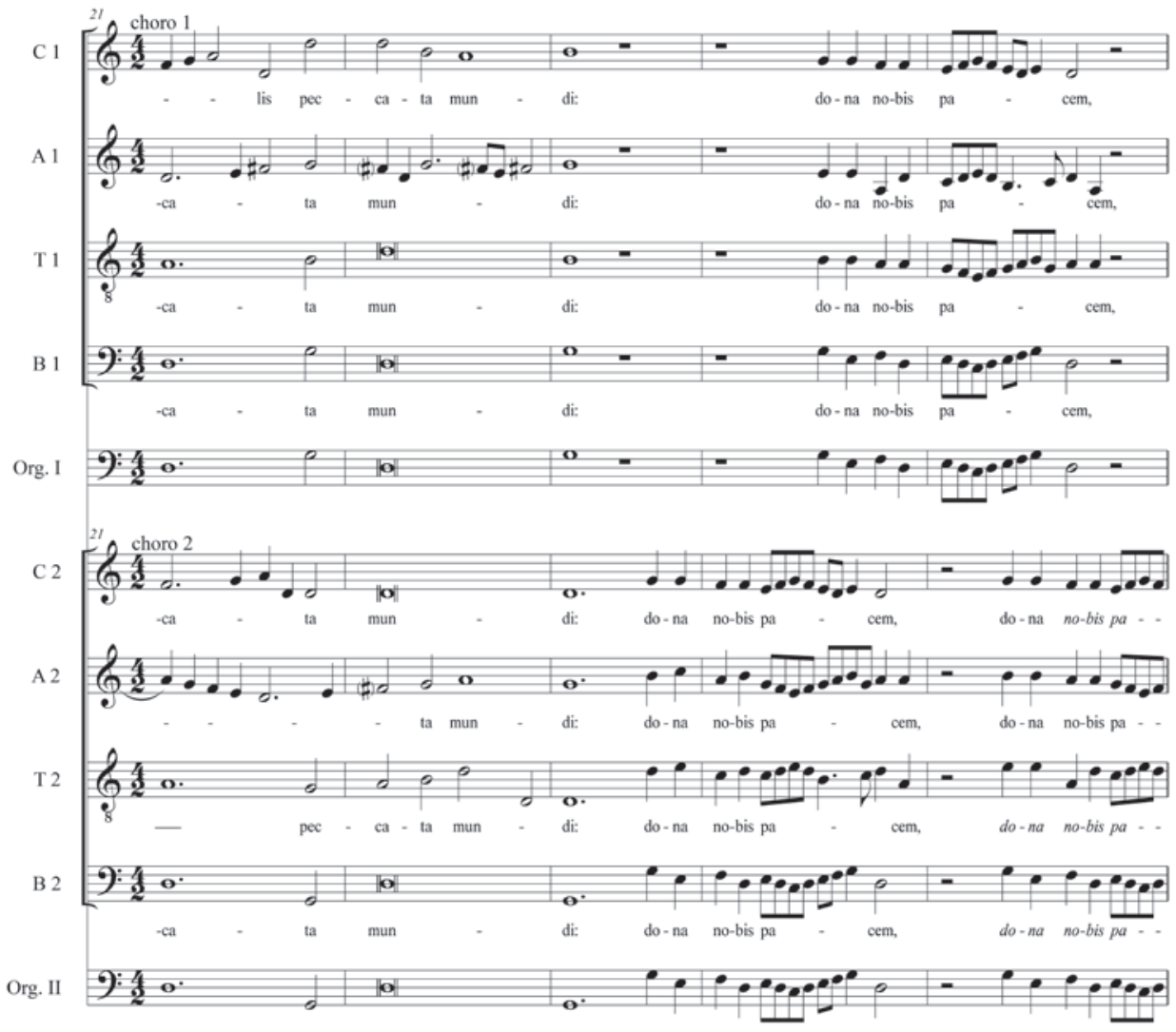

\section{Appendix}

Selected incipits of Ertel's Magnificats from his 1615 collection Sacrosanctum and their respective models

Sebastian Ertel, Magnificat super Ecco la vaga aurora (no. I)

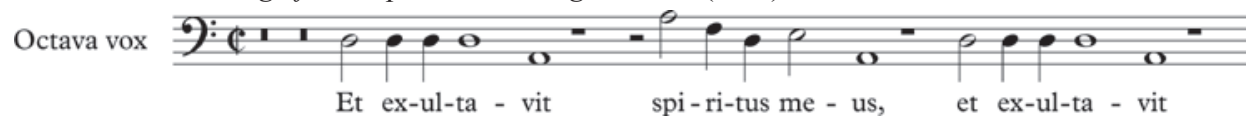

Andrea Gabrieli, Ecco la vaga aurora (a 8) from Concerti di Andrea, et di Gio. Gabrieli (1587)

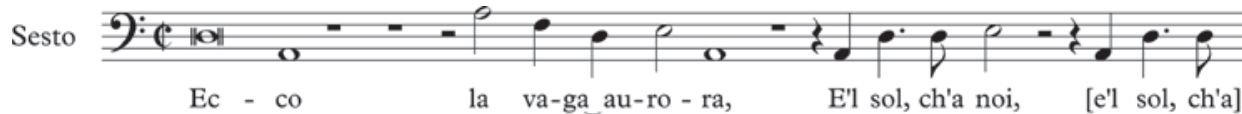


Sebastian Ertel, Magnificat super Si qua rubent (no. VII)

Octava vox

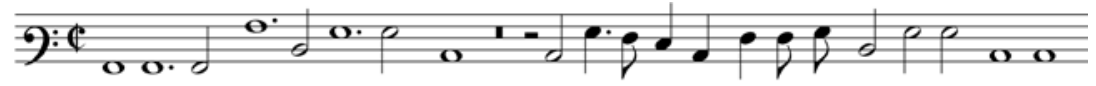

A-ni-ma me-a Do-mi-num. Et ex-ul-ta-vit spi-ri-tus me-us in De-o

Annibale Perini, Si qua rubent (a 8) from a collective manuscript now in Växjö

[Bassus]

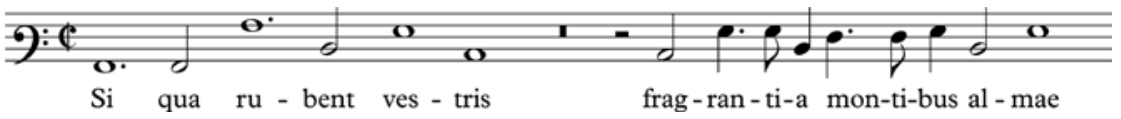

Sebastian Ertel, Magnificat super Jubilate Deo (no. VIII)

Tenor

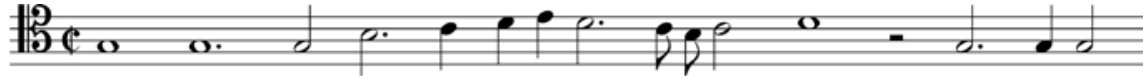

Et ex - ul - ta - $\quad-\quad$ - $\quad$ - vit

Andrea Gabrieli, Jubilate Deo (a 8) from Concerti di Andrea, et di Gio. Gabrieli (1587)

Tenor

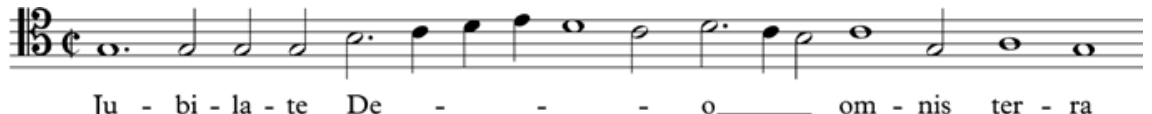

$$
\text { Ju - bi - la - te De - } \quad \text { - } \quad \text { - o_ om - nis ter - ra }
$$

Sebastian Ertel, Magnificat super Iniquos odio habui (no. XIV)

Cantus

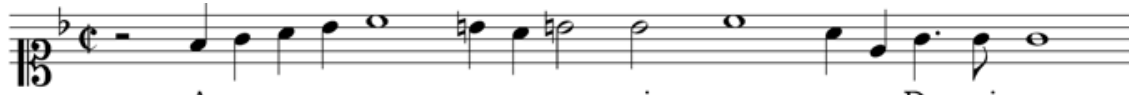

$$
\text { A - } \quad \text { - } \quad \text { - } \quad \text { - ni - ma me-a Do-mi-num }
$$

Luca Marenzio, Iniquos odio habui (a 8) from Promptuarii musici [...] Pars Prima (1611)

Cantus

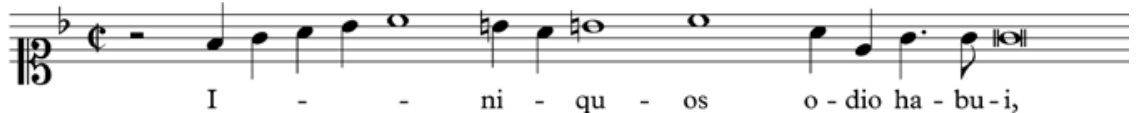

Sebastian Ertel, Magnificat super Hoc tegitur (no. XV)

Altus

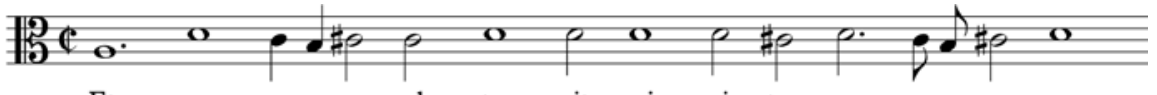

Et ex - ul - ta - vit spi - ri - tus me - us

Giovanni Gabrieli, Hoc tegitur (a 8) from Sacrae symphoniae (1597)

Sextus

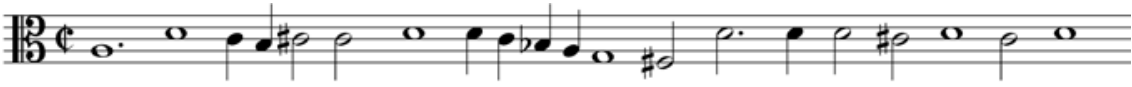

Hoc te - gi - tur sa - cro quis-nam ve - la - mi-ne

Sebastian Ertel, Magnificat super Beati omnes (no. XVIII)

Sexta vox

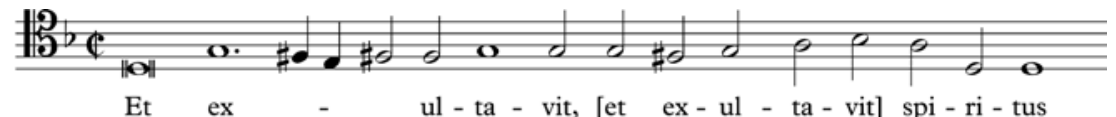

Giovanni Gabrieli, Beati omnes (a 8) from Sacrae symphoniae (1597)

Octavus

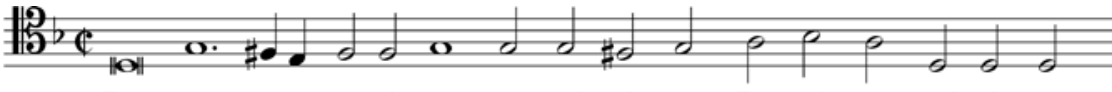

Be - a - ti om-nes qui ti-ment Do-mi-num, qui ti-ment

Sebastian Ertel, Magnificat super Domine quis habitabit (no. XXVI)

Bassus

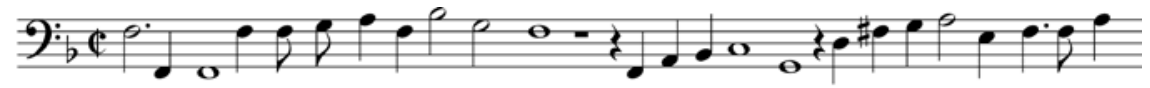

A-ni-ma, a - ni-ma me-a Do-mi-num. Et ex-ul-ta - vit, [et ex-ul-ta-vit] spi-ri-tus 
Leone Leoni, Domine, quis habitabit (a 8) from a collective manuscript now in Gdańsk

Bassus

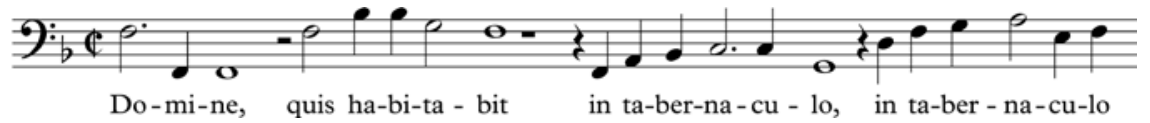

\section{Sources and Bibliography}

Archival And Manuscript Sources

Linz, Oberösterreichisches Landesarchiv, Actenstück - Bericht über den Tumult zu Steyr 1599. Stiftsarchiv Garsten, Aktenband 69/Nr. 12.

Växjö, Stiftsbiblioteket, Växjö Stadsbibliotek, Musik 15-1600-tal Ms 2c-e. RISM 190013220.

Gdańsk, Biblioteka Gdańska Polskiej Akademii Nauk, Ms. 4010 and Ms. 4012. RISM 305000446.

\section{EARLY PRINTS}

Ertel, Sebastian. Missarum sex, septem, octo, et decem vocibus ad organum accommodatis. Munich: Nicolaus Henricus, 1613. RISM E 783. https://bildsuche.digitalesammlungen.de/index.html? $\mathrm{c}=$ viewer\&l$=$ fr\&bandnummer $=\mathrm{bsb} 00010070 \&$ pimage $=00010070 \& \mathrm{v}=\&$ nav $=$.

- Psalmodiae vespertinae, solemnibus totius anni festivitatibus octonis vocibus, et tam vocum quam variorum instrumentorum usui, accommodatae, quibus accesserunt canticum Deiparae Virginis [...] cum basso ad organum. Munich: Nicolaus Henricus, 1617. RISM E 785.

___ Sacrosanctum magnae et intemeratae Virginis canticum, octonis vocibus, cum intonationibus psalmorum ad octo usitatos tonos duobus choris una cum clausula Gloria Patri etc. qua instrumentis, qua vivis vocibus cum duplici basso ad organum accomodato. Munich: Nicolaus Henricus, 1615. RISM E 784 and EE 784.

___ Symphoniae sacrae, ad Dei divorumque laudes in ecclesia qua instrumentis, qua vivis hominum vocibus decantandas accommodatae, quibus sexta vox initium, decima vero finem dabit. Munich: Nicolaus Henricus, 1611. RISM E 782.

Gabrieli, Andrea, and Giovanni Gabrieli. Concerti [...] continenti musica di chiesa, madrigali, \& altro, per voci, \& stromenti musicali, a 6, 7, 8, 10, 12, \& 16 [...] libro primo et secondo. Venice: Angelo Gardano, 1587. RISM $1587^{16}$.

Gabrieli, Giovanni. Sacrae symphoniae [...] senis, 7, 8, 10, 12, 14, 15, \& 16, tam vocibus, quam instrumentis, editio nova. Venice: Angelo Gardano, 1597. RISM G 86 and GG 86.

Poss, Georg. Orpheus mixtus vel, si mavis concentus musici, tam sacris, quam profanis usibus elaborati, tam simulatis instrumentorum [...] quibus vox octava initium sextadecima finem scribit. Graz: Georg Widmanstetter, 1607. RISM P 5246.

Schadaeus, Abraham, ed. Promptuarii musici, sacras harmonias sive motetas V. VI. VII. \& VIII vocum, e diversis [...] autoribus, antehac nunquam in Germania editis [...] Pars Prima. Strasbourg: Karl Kieffer, 1611. RISM 1611. 


\section{LITERATURE}

Eitner, Robert. “Erthel, Sebastian”. In Biographisch-Bibliographisches Quellen-Lexikon, 3:352. Graz: Akademische Druck- und Verlagsanstalt, 1959.

Garstenauer, Günter, ed. P. Ernest Koch-Biographien. Äbte und Mönche des Klosters Garsten. Beiträge zur Geschichte des Klosters Garsten und der Stadt Steyr, 2. Neuzeug: Eigenverlag, 2011.

Gruber, Gernot. Beiträge zur Geschichte und Kompositionstechnik des Parodiemagnificat in der 2. Hälfte des 16. Jahrhunderts. PhD diss., Karl-Franzens-Universität Graz, 1964.

Haider, Siegfried. Studien zu den Traditionsbüchern des Klosters Garsten. Vienna: R. Oldenbourg Verlag im Veritas Bildungsverlag, 2008. https://doi.org/10.7767/ boehlau.9783205160878.

Huemer, Georg. Die Pflege der Musik im Stifte Kremsmünster: Cultur-Historischer Beitrag zur E(i)lften Säcular-Feier. Wels: Druck und Verlag von Johann Haas, 1877.

Kellner, Altman. Musikgeschichte des Stiftes Kremsmünster-nach den Quellen dargestellt. Kassel: Bärenreiter, 1956.

Kollbacher, Adolf. Musikpflege in Mariazell: Drei Generationen der Komponistenfamilie Widerhofer 1756-1876 (mit einem Thematischen Katalog ihrer Werke). Vienna: Böhlau Verlag, 1995.

Mecenseffy, Grete. Geschichte des Protestantismus in Österreich. Graz: Hermann Böhlaus Nachfolger, 1956.

Moser, Hans Joachim. Die Musik im frühevangelischen Österreich. Kassel: Johann Philipp Hinnenthal-Verlag, 1954.

Moser, Josef, and Barbara Weber. Waidhofen an der Ybbs und Steyr im Blick: Die „Annalen“ (1590-1622) des Schulmeisters Wolfgang Lindner in deutscher Übersetzung. Edited by Martin Scheutz. Forschungen zur Landeskunde von Niederösterreich, 35. St. Pölten: Verein für Landeskunde von Niederösterreich, 2012.

Mutschlechner, Renate. "Ertl, Sebastian". In The New Grove Dictionary of Music and Musicians, 2nd ed., edited by Stanley Sadie, 8:309. London: Macmillan, 2001.

Neumann, Ilse. Steyr und die Glaubenskämpfe-1. Teil. Veröffentlichungen des Kulturamtes der Stadt Steyr. Steyr: Kulturamt der Stadt Steyr, 1952.

Plank, Benedikt. Geschichte der Abtei St. Lambrecht: Festschrift zur 900. Wiederkehr des Todestages des Gründers Markward von Eppenstein 1076-1976; Verfasst vom Stiftsarchivar P. Benedikt Plank. St. Lambrecht: Stift St. Lambrecht, 1978.

Pritz, Franz Xaver. Beschreibung und Geschichte der Stadt Steyr und ihrer nächsten Umgebung nebst mehreren Beilagen betreffend die Geschichte der Eisengewerkschaft und der Klöster Garsten und Gleink. Steyr: Verlag Wilhelm Ennsthaler, 1993.

. Geschichte der ehemaligen Benediktinerklöster Garsten und Gleink im Lande ob der Enns und der dazugehörigen Pfarren. Steyr: Verlag Wilhelm Ennsthaler, 1984.

Rolleder, Anton. Heimatkunde von Steyr. Historisch-topographische Schilderung der politischen Bezirke Steyr Stadt und Land. Steyr: Verlag Wilhelm Ennsthaler, 1993.

Wessely, Othmar. Musik in Oberösterreich. Schriftenreihe des Institutes für Landeskunde von Oberösterreich. Linz: Oberösterreichischer Landesverlag, 1951.

Zahn, Johannes, ed. "Peter Weixler's Chronik des Stiftes St. Lambrecht, Auszüge nach dem Originale, geschrieben c. 1635". Steiermärkische Geschichtsblätter 6 (1885): $1-27,65-79,129-161$. 


\section{P. SEBASTIAN ERTEL IN NJEGOVA DUHOVNA DELA}

\section{Povzetek}

Kratek pregled življenja in dela benediktinskega očeta Sebastiana Ertla skuša prikazati možne povezave tega skladatelja in njegovega sloga z graško dvorno kapelo in drugimi glasbenimi središči, kot so bile Benetke in München. Tako širše zanimanje za »novi« fenomen v italijanski glasbi kot tudi osebna glasbena naklonjenost nadvojvode Ferdinanda sta nedvomno vplivala na glasbeno-slogovno usmeritev graške dvorne kapele, a ne samo te, temveč tudi na slog Sebastiana Ertla.

Ertlov kontakt z novo italijansko glasbo je razumljiv, saj je posledica živahnih stikov med benediktinci in univerzo ter mestom Gradec in tudi njegovih prizadevanj v protireformacijskem gibanju, še posebno v kraju St. Lambrecht in Mariazell na Štajerskem. Čeprav je bil Garsten, Ertlovo zadnje domovanje, pod močnim nemškim vplivom, so zanj zelo pomembni tudi njegovi glasbeni vzori. Pri tem je treba omeniti, da je bil Steyer v skladateljevem času še pod močnim protestantskim vplivom in so v tamkajšnjih cerkvah izvajali glasbo skladateljev, kot so na primer Jakob Regnart, Leonhard Paminger, Orlando di Lasso in tudi Jacobus Handl - Gallus. V cerkvi evangeličanske šole v Steyerju je med 1609 in 1625 kot organist delal skladatelj Paul Peuerl in leta 1606 sta mestnemu svetu poklonila nekaj motetov Orlanda di Lassa njegova sinova Ferdinand in Rudolf di Lasso. $\mathrm{Na}$ tem mestu je treba poudariti tudi dejstvo, da je vse glasbene zbirke Sebastiana Ertla natisnil münchenski tiskar Nicolaus Heinrich.

Čeprav je Ertel skladal predvsem za potrebe svojih samostanov, je vsekakor tudi mednarodno zanimiv, še posebno, če njegova dela primerjamo z njegovimi italijanskimi vzori in modeli, kar bi bilo dobro še natančno raziskati. Zanimivo bi bilo preučiti, kaj je pripeljalo do dejstva, da se njegova dela danes nahajajo v številnih evropskih knjižnicah, od Berlina, Coburga, Strasbourga, Vroclava, Regensburga, Dresdna, Münchna do Levoče itd., in zakaj so številne skladbe iz njegovih zbirk Symphoniae Sacrae (1611) in Sacrosanctum (1615) prisotne v I., II., V. in VI. zvezku Peplinskih orgelskih tabulatur. 